\title{
Key Success Factor Analysis in Application of Manual Pert Method in Rail Road Construction
}

\author{
${ }^{1}$ Yogi Argiansyah, Budi Susetyo ${ }^{2}$ \& Fuad Fahmi ${ }^{3}$ \\ ${ }^{1-3}$ Department of Civil Engineering \\ Mercu Buana University \\ Jakarta, Indonesia
}

\begin{abstract}
Project success is the ultimate goal of every project. The difference in critical success factors for a project is because each project has different factors of influence. Therefore, each party involved must have a certain strategy for the success of the project, namely by knowing the factors that most influence the success (success) of the construction implementation.

Methodology This research was conducted using a qualitative descriptive research method by explaining variables and processing the data at the stage of identification and factor analysis. Distributed to 40 respondents who are involved in railroad works. The purpose of this study is to describe a number of variables with respect to the problem and the unit studied between the problems being tested, and to determine the success factors.

Distributed to 40 respondents who are involved in railroad works. The purpose of this study is to describe a number of variables with respect to the problem and the unit studied between the problems being tested, and to determine the success factors. And the manual method pert $\left(\mathrm{X}_{2}\right)$ with 14 factors consists of the distribution of activity duration, the effect of activity duration, the work must be faster, the possibility of sharing activity duration, scheduling arrangements, the final goal of project scheduling, scheduling activities that can be completed on time, break down or start. Project into activities, determine the estimated network time, network diagrams are drawn, can combine project activities, calculations can be developed manually, a higher similarity in the scheduled network, the resulting tool is accurate but not complicated. These factors, namely the Implementation Method $\left(\mathrm{X}_{1}\right)$ and the Manual Method Pert $\left(\mathrm{X}_{2}\right)$ affect the time dependent variable (Y).
\end{abstract}

Keywords: PERT, M- Pert, Rail Road Construction, Time Delay.

\section{INTRODUCTION}

The Indonesian government is targeting the construction of a new railway network by 2030 to reach $13,000 \mathrm{~km}$. Currently, Indonesia only has $6,000 \mathrm{~km}$ of railway lines. This means that within 11 years, Indonesia will build 7,000 new railroads. As a mode of land transportation in the field implementation of railroad construction projects in several countries in the world, there are delays resulting in time delays and Flyvjberg's analysis found that railroad construction projects experience cost overruns by 28 percent, bridge and tunnel projects by 34 percent, and road projects by 21 percent. Matthews's 2016 research also explains the delay in construction projects in several European, Asian and African countries with the percentage of delays ranging from $10 \%$ to $130 \%$. Average time and cost overruns in a sample of 145 public sector construction projects in 8 countries. Time management is important in any construction project. Without proper time management, many problems will occur such as overtime or time overrun. Some researchers describe time overrun as delay and some of them describe time overrun as the effect of construction delay, whatever it is, delay is the most common problem in the construction industry worldwide (Memon, Rahman, Ismail, \& Zainun, 2014). According to Taufan (2016), delay in project time is an event that always occurs in every project. In this case, especially for Service Providers, delays in the project will result in a delay which will reduce the profit that has been targeted by the contractor in charge of the project. So that the target of the planned development program is not as expected. Time delays can also be caused by the influence of the surrounding environment, unpreparedness of the land as a place to be used as a project location, poor project management implemented and also mistakes in human resources. Based on the aforementioned problems, this research is conducted to see what factors can influence the time delay on railroad construction work. So it is hoped that 
knowing these factors can help contractors in minimizing time delays in the completion of construction projects, especially from the aspect of rail road construction work in Indonesia.

\section{FORMULATION OF THE PROBLEM}

Based on the description on the background above, the problem in this study can be formulated which are the factors that influence the application of the M-PERT and Earned-Value Analysis methods on rail road infrastructure development projects.

\section{RESEARCH OBJECTIVES}

This study aims to analyze the most influencing factors in the application of the M-PERT and Earned-Value Analysis methods in rail road infrastructure development projects.

\subsection{SCOPE}

The research was conducted at several construction service companies engaged in rail road infrastructure project work. This study only includes pavement work and rail road construction. This study does not discuss quality performance on railroad projects.

\section{LITERATURE}

The main key to the success of implementing a project on time is complete and precise project planning and scheduling. Delay can be considered as a result of not fulfilling the schedule plan that has been made, because the reality conditions are not the same / according to the conditions when the schedule was made. Research was carried out on several construction service companies engaged in rail road infrastructure project work.

Critical Success Factors or CSF's are factors or responses that are critical to the successful implementation of a project that must be done where without these factors the project will not be successful or successful in achieving certain targets or goals on a project or job. Critical Success Factors are very important to identify before the project starts. The concept of success factors was developed by D. Ronald Daniel of McKinsey \& Company in 1961. Then sharpened into critical success factors by John F. Rockart between 1979-1981. After that this concept is widely used in various epresen fields including projects. Specifically for projects, there are at least five elements that are of concern in determining critical success factors, namely Project Manager, Project Team, Project itself, Organization and External Environment.

\subsection{Scheduling}

In reality, the scheduling procedure through the estimation process contains an element of uncertainty. This is in accordance with the characteristics of a construction project, namely a high level of risk to any changes that occur, whether changes in the political system, weather, dependence on labor, construction failure, dependence on other parties, and so on. Scheduling is an activity to determine the time required and the sequence of activities and determine the time the project can be completed (Ervianto, 2002). Scheduling is thinking deeply through various problems, testing logical paths, and arranging various kinds of tasks that result in a complete activity, and writing down various activities in a logical order and in the right time series (Luthan, 2006). In reality, the scheduling procedure through the estimation process contains an element of uncertainty. This is in accordance with the characteristics of a construction project, namely a high level of risk to any changes that occur, whether changes in the political system, weather, dependence on labor, construction failure, dependence on other parties, and so on.There are several methods of scheduling construction projects, including the following.

\subsubsection{Program Evaluation And Review Techniquee (PERT)}

Program Evaluation \& Review Technique (PERT) is a method that aims to reduce delays, disruptions and production conflicts as much as possible; coordinate and synchronize the various parts as a whole work; and speeding up project completion, (Levin and Kirkpatrick, 1977). PERT is a project management tool that is used to schedule, organize and coordinate parts of work in a project. Program Evaluation Review Technique (PERT) is a scheduling method by considering the duration of an activity that is uncertain. (Andreas Wibowo 2001).

\subsection{Manual Pert (M-PERT)}

The M-PERT method was first introduced by Pablo Ballesteros Perez, Ph.D in July 2017. For an example of bridge work using the PERT method, a Manual Program Evaluation and Review Technique (M-PERT) was carried out. M-PERT allows manual computation via a recursive coupling procedure that downsizes the network until the last activity represents the entire (or 
remaining) duration of the project. Therefore, M-PERT is an interesting tool for teaching the basics of scheduling to students in a more intuitive way, with or without the help of computer-based simulations or software one complete case study is described and a future research path is suggested. Perez (2017).

\section{RESEARCH METHODOLOGY}

\subsection{Types of research}

Methodology This research was conducted using a qualitative descriptive research method by explaining variables and processing the data at the stage of factor identification and factor analysis. The purpose of this study is to describe a number of variables relating to the problem and the unit under study between the problems being tested, and to determine the identification of factors and their analysis.

The research method framework can be seen in the following figure:

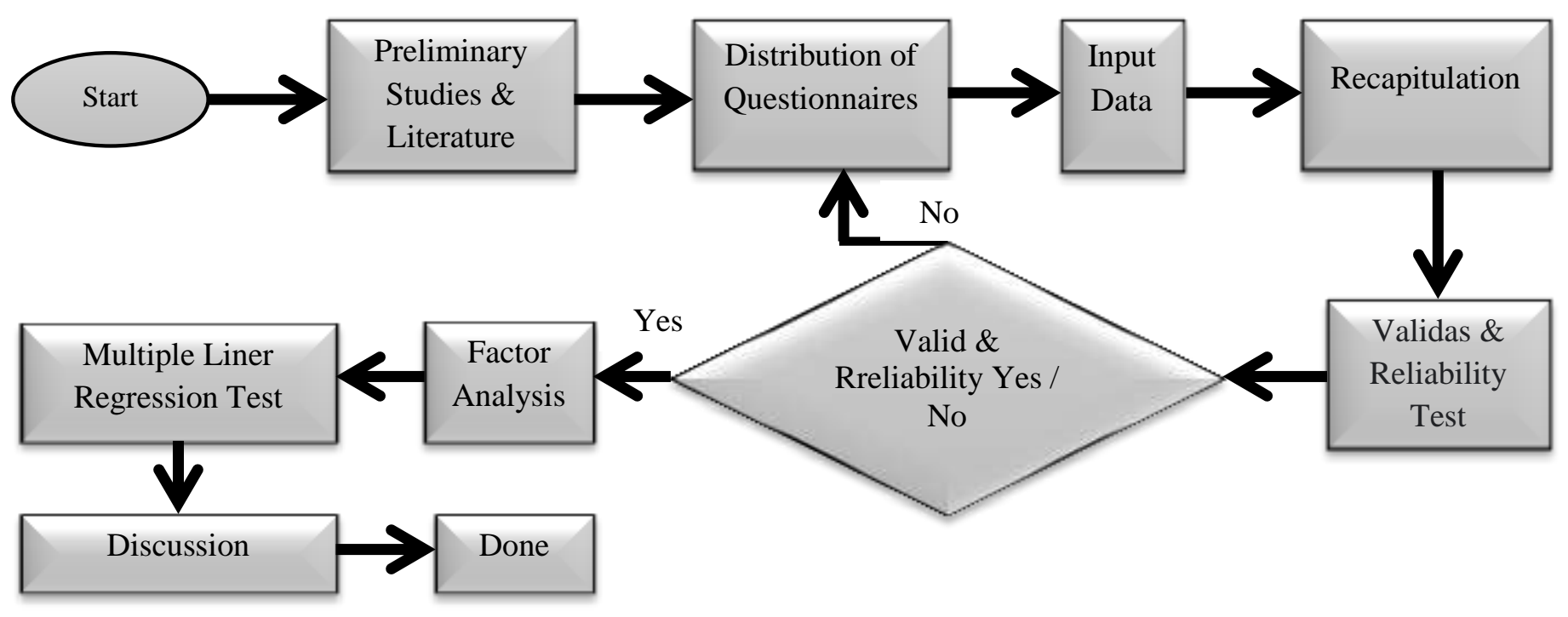

Picture 1. Research Stages

\subsection{Data collection}

This data collection activity is an important stage to do so that this research can be carried out. Data collection is divided into 2 (two) types, namely primary data and secondary data (reference data). Primary data obtained from filling out questionnaires and interviews with experts about the assessment of factors in railroad construction work.

The instrument used was a questionnaire in the form of a checklist. The steps for preparing the instrument begin with their translation into variables, indicators and their components. All questions arranged are placed on the questionnaire instrument sheet. 
International Journal of Engineering Research And Advanced Technology, Vol.7 (3), March -2021

\subsection{Questionnaire Design}

\begin{tabular}{|c|c|c|c|c|}
\hline \multicolumn{2}{|c|}{ Main Factors } & \multirow{2}{*}{ Code } & \multirow{2}{*}{ Sub } & \multirow{2}{*}{ Source } \\
\hline No & Name & & & \\
\hline \multirow{11}{*}{1} & \multirow{11}{*}{$\begin{array}{l}\text { Method Of } \\
\text { Implementation Of Rel } \\
\text { Road Construction Work } \\
\text { (X1) }\end{array}$} & 1 & Selection of alignment and geometric planning & Carpenter (1996) \\
\hline & & 2 & Work environment & Tiong Iskandar ( 2013 ) \\
\hline & & 3 & Lay-out arrangement for easy delivery / service & Tiong Iskandar ( 2013 ) \\
\hline & & 4 & Availability of materials & Tiong Iskandar ( 2013 ) \\
\hline & & 5 & Excavator selection & (Misnan M.S, 2002) \\
\hline & & 6 & Excavator size & (Misnan M.S, 2002) \\
\hline & & 7 & Monitor cut \& fill & (Misnan M.S, 2002) \\
\hline & & 8 & Skilled operator & (Misnan M.S, 2002) \\
\hline & & 9 & Working Methods for Distribution & Carpenter (1996) \\
\hline & & 10 & Experience in similar jobs & Carpenter (1996) \\
\hline & & 11 & Human Resources Required & Carpenter (1996) \\
\hline
\end{tabular}

\begin{tabular}{|c|c|c|c|c|}
\hline & & 1 & Activity duration distribution & Zachary (2018) \\
\hline & & 2 & Effects of duration of activity & Zachary (2018) \\
\hline & & 3 & Work must be faster & Zachary (2018) \\
\hline & & 4 & Possible sharing of activity duration & Zachary (2018) \\
\hline & & 5 & Scheduling arrangement & Zachary (2018) \\
\hline & & 6 & The ultimate goal of project scheduling & Syal Matt (2014) \\
\hline & APPLICATION & 7 & Scheduling activities can be completed on time & Syal Matt (2014) \\
\hline 2 & (X2) METHOD & 8 & $\begin{array}{l}\text { Breaking down or starting a project into } \\
\text { activities }\end{array}$ & Pablo (2017) \\
\hline & & 9 & Determines the estimated network time & Pablo (2017) \\
\hline & & 10 & Network diagram is depicted & Zachary (2018) \\
\hline & & 11 & Can combine project activities & Pablo (2017) \\
\hline & & 12 & Calculations can be developed manually & Pablo (2017) \\
\hline & & 13 & Higher similarity in scheduled networks & Pablo (2017) \\
\hline & & 14 & $\begin{array}{l}\text { The resulting tool is accurate but not } \\
\text { complicated }\end{array}$ & Pablo (2017) \\
\hline
\end{tabular}


International Journal of Engineering Research And Advanced Technology, Vol.7 (3), March -2021

\begin{tabular}{|l|l|l|l|l|}
\hline \multirow{2}{*}{5} & \multirow{2}{*}{ Time (Y) } & 1 & Changes to the design of the building & Rahman et (2013 ) \\
\cline { 3 - 5 } & 2 & Be on time in payment & Rahman et (2013 ) \\
\cline { 3 - 5 } & 3 & Machine working hours & Shapiraet al (2013) \\
\cline { 3 - 5 } & 4 & Workers cannot meet working hours & Jose Ramon (2013) \\
\cline { 3 - 5 } & 5 & Improper maintenance of the railroad & San Cristobal ( 2013 ) \\
\hline
\end{tabular}

Table 1 Questionnaire table

\section{ANALYSIS AND DISCUSSION}

\subsection{Respondent Data}

\subsection{Respondent Characteristics}
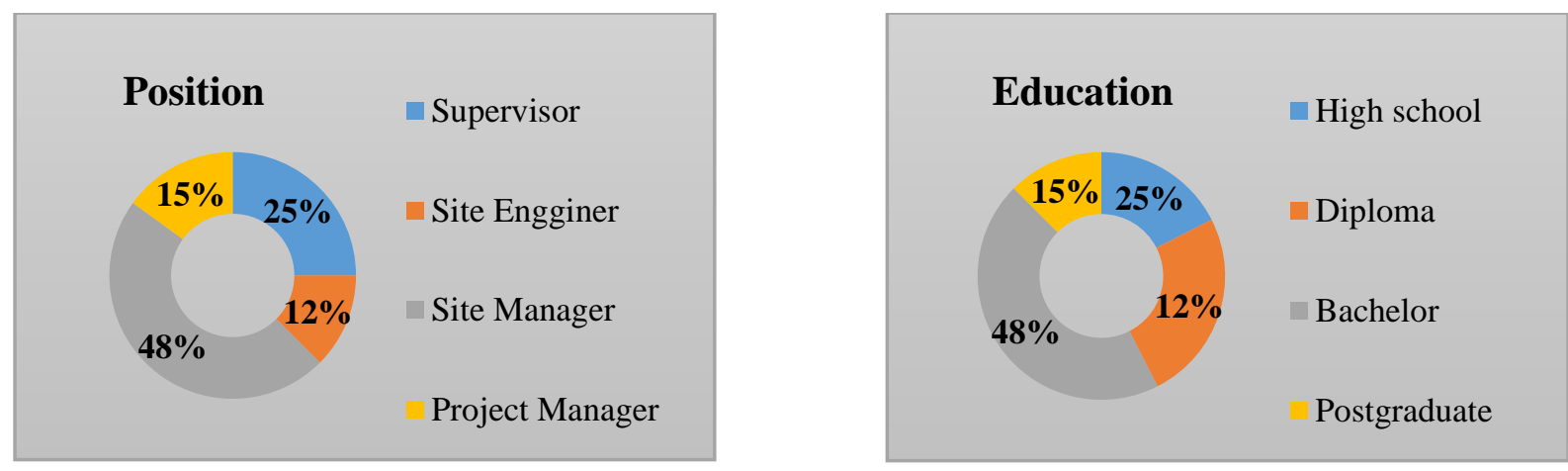

\section{Education}

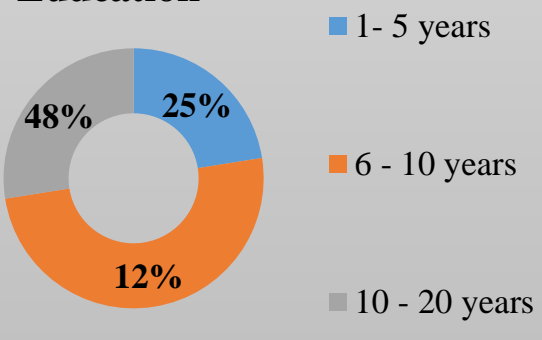

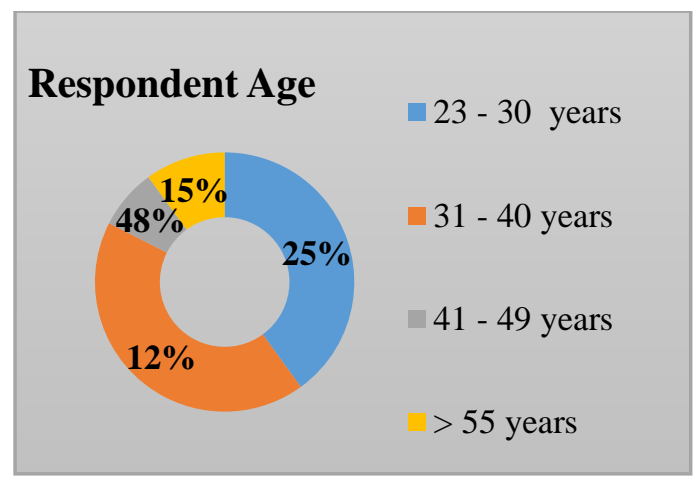
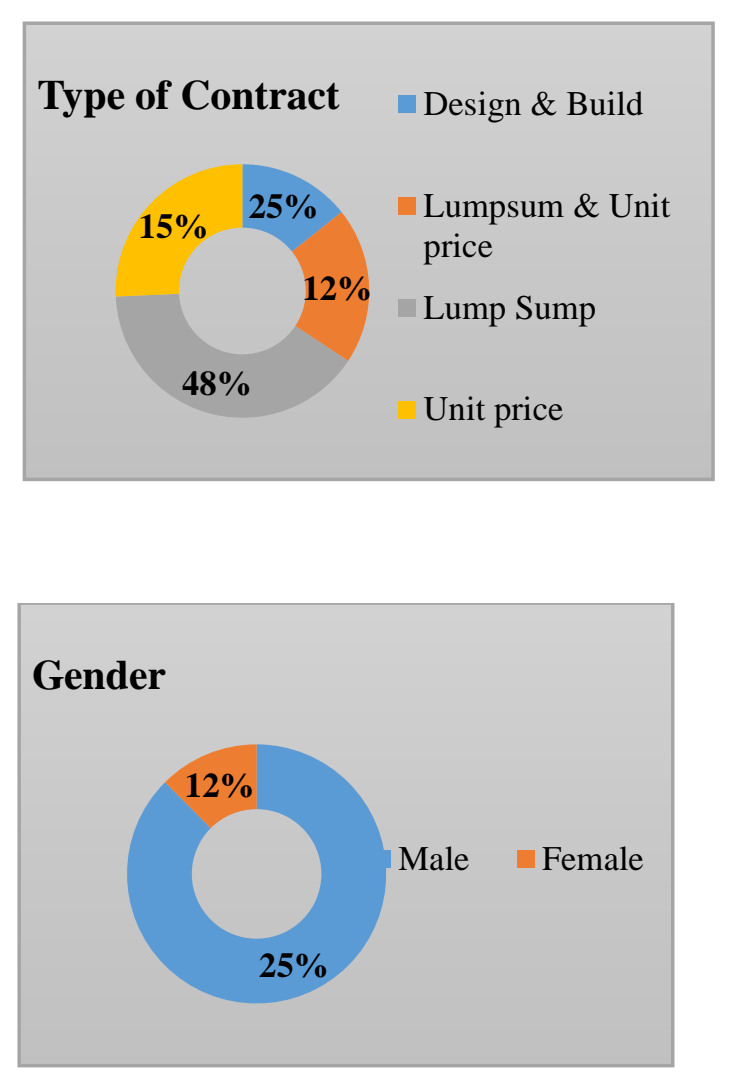

Figure 2. Respondent Data 
International Journal of Engineering Research And Advanced Technology, Vol.7 (3), March -2021

\subsection{Validity Testing}

The validity test can be done by correlating the question items with the total construct or variable score (Ghozali, 2013). Or you can also compare the calculated $r$ value with $r$ table, if the value:

If $r$ count $>r$ table, then the result is valid

If $r$ count $<r$ table, then the result is invalid

The validity test program was carried out with the help of the SPSS 24 software for each variable. Namely the variables X1, X2 which will affect the dependent variable Y.

The total variables that the researcher collected were 30 variables with 40 respondents, the results of which were declared valid for all values of $r$ count $>r$ variable.

In the research data processing process, the data collected was tested for validity and reliability test for each variable to determine its validity and reliability.

Table 2 Variable Validity Test (X1)

\begin{tabular}{|l|l|l|l|l|}
\hline Code & Method of Implementation $(\mathrm{X} 1)$ & $\mathrm{r}$ count & $\mathrm{r}$ table & Information \\
\hline $\mathrm{X} 1.1$ & Selection of geometric alignment and planning & 0,800 & 0,312 & VALID \\
\hline $\mathrm{X} 1.2$ & Work environment & 0,729 & 0,312 & VALID \\
\hline $\mathrm{X} 1.3$ & Lay-out arrangement for easy delivery / service & 0,725 & 0,312 & VALID \\
\hline $\mathrm{X} 1.4$ & Availability of materials & 0,828 & 0,312 & VALID \\
\hline $\mathrm{X} 1.5$ & Excavator selection & 0,734 & 0,312 & VALID \\
\hline $\mathrm{X} 1.6$ & Excavator size & 0,772 & 0,312 & VALID \\
\hline $\mathrm{X} 1.7$ & Monitor cut \& fill & 0,710 & 0,312 & VALID \\
\hline $\mathrm{X} 1.8$ & Skilled operator & 0,763 & 0,312 & VALID \\
\hline $\mathrm{X} 1.9$ & Working Methods for Distribution & 0,710 & 0,312 & VALID \\
\hline $\mathrm{X} 1.10$ & Experience in similar jobs & 0,766 & 0,312 & VALID \\
\hline $\mathrm{X} 1.11$ & Human Resources Required & 0,565 & 0,312 & VALID \\
\hline
\end{tabular}

Sumber: Data primer yang diolah dengan SPSS 22

Table 3 Uji Validitas Variabel (X2)

\begin{tabular}{|l|l|l|l|l|}
\hline Code & Method of Implementation ( X1 ) & r count & $\mathrm{r}$ table & Information \\
\hline $\mathrm{X} 2.1$ & Activity duration distribution & 0.893 & 0,312 & VALID \\
\hline $\mathrm{X} 2.2$ & Effects of duration of activity & 0.904 & 0,312 & VALID \\
\hline $\mathrm{X} 2.3$ & Work must be faster & 0.885 & 0,312 & VALID \\
\hline $\mathrm{X} 2.4$ & Possible sharing of activity duration & 0.675 & 0,312 & VALID \\
\hline
\end{tabular}


International Journal of Engineering Research And Advanced Technology, Vol.7 (3), March -2021

\begin{tabular}{|l|l|l|l|l|}
\hline X2.5 & Scheduling arrangement & 0.918 & 0,312 & VALID \\
\hline X2.6 & The ultimate goal of project scheduling & 0.918 & 0,312 & VALID \\
\hline X2.7 & Scheduling activities can be completed on time & 0.334 & 0,312 & VALID \\
\hline X2.8 & Breaking down or starting a project into activities & 0.631 & 0,312 & VALID \\
\hline X2.9 & Determines the estimated network time & 0.348 & 0,312 & VALID \\
\hline X2.10 & Network diagram is depicted & 0.826 & 0,312 & VALID \\
\hline X2.11 & Can combine project activities & 0.789 & 0,312 & VALID \\
\hline X2.12 & Calculations can be developed manually & 0.771 & 0,312 & VALID \\
\hline X2.13 & Higher similarity in scheduled networks & 0.789 & 0,312 & VALID \\
\hline X2.14 & The resulting tool is accurate but not complicated & 0.893 & 0,312 & VALID \\
\hline
\end{tabular}

Source: Primary data processed by SPSS 22

Table 4 Variable Validity Test (Y)

\begin{tabular}{|l|l|l|l|l|}
\hline Code & Time Indicator (Y) & r count & r table & Information \\
\hline 1 & Changes to the design of the building & 0,864 & 0,312 & VALID \\
\hline 2 & Be on time in payment & 0,723 & 0,312 & VALID \\
\hline 3 & Machine working hours & 0,879 & 0,312 & VALID \\
\hline 4 & Workers cannot meet working hours & 0,839 & 0,312 & VALID \\
\hline 5 & Improper maintenance of the railroad & 0,812 & 0,312 & VALID \\
\hline
\end{tabular}

Source: Primary data processed by SPSS 22

\subsection{Reliability Testing}

Cronbach's alpha reliability coefficient normally ranges between 0 and 1 (Joseph A and Rosemary R 2003). While the criteria set for the reliability test are if the Cronbach's alpha value is greater than 0.60 then it can be categorized as reliable. The results of calculations on variables X1, X2, and Y with 30 statements have a Cronbach's alpha value of 0.910 (>0.60) so that the variable has been declared reliable or that the variable data is fixed.

\subsection{Normality test}

A good regression model is to have a residual value that is normally distributed so that the Kolmogorov-Smirnov test is carried out if the significance value is $>0.05$ then the regression model is normally distributed. The results of the spss value show $0.616>$ 0.05 , meaning that the variables $\mathrm{X} 1, \mathrm{X} 2$ have an effect on variable $\mathrm{Y}$. 
International Journal of Engineering Research And Advanced Technology, Vol.7 (3), March -2021

Table 5 Normality Test

\begin{tabular}{|c|c|c|}
\hline \multicolumn{3}{|c|}{ One-Sample Kolmogorov-Smirnov Test } \\
\hline & & Unstandardized Residual \\
\hline \multicolumn{2}{|l|}{$\mathbf{N}$} & 40 \\
\hline \multirow{2}{*}{ Normal Parametersa,b } & Mean & $0 \mathrm{E}-7$ \\
\hline & Std. Deviation & 1,17637791 \\
\hline \multirow{3}{*}{ Most Extreme Differences } & Absolute &, 120 \\
\hline & Positive &, 094 \\
\hline & Negative &,- 120 \\
\hline \multicolumn{2}{|l|}{ Kolmogorov-Smirnov Z } & ,757 \\
\hline Asymp. Sig. (2-tailed) & & ,616 \\
\hline
\end{tabular}

a. Test distribution is Normal.

b. Calculated from data.

Source: Primary data processed by SPSS 22

\subsection{Multiple Linear Regression Analysis}

Multiple linear regression analysis is used to determine the effect of independent variable indicators on the dependent variable (Sugiyono, 2013). Multiple linear regression analysis was conducted to determine the regression coefficient or the influence of the independent variable (X1) the method of work implementation and (X2) the method of pert \& m pert to Y (time). In this study, using multiple linear regression analysis because it has more than one independent variable.

Table 6 Multiple Linear Regression Test

\begin{tabular}{|l|l|l|l|l|}
\hline \multicolumn{4}{|l|}{ Model Summary } \\
\hline Model & R & R Square & Adjusted R Square & Std. Error of the Estimate \\
\hline 1 &, $925 \mathrm{a}$ &, 856 &, 848 & 1,208 \\
\hline
\end{tabular}

a. Predictors: (Constant), X2, X1

Source: Primary data processed by SPSS 22

Table 7 Multiple Linear Regression Test

\begin{tabular}{|l|l|l|l|l|l|l|}
\hline \multicolumn{2}{|c|}{ Sum of Squares } & df & Mean Square & F & Sig. \\
\hline \multicolumn{1}{|l|}{ Model } & Regression & 319,804 & 2 & 159,902 & 109,622 &, $000 \mathrm{~b}$ \\
\cline { 2 - 7 } & Residual & 53,971 & 37 & 1,459 & & \\
& Total & 373,775 & 39 & & & \\
\hline
\end{tabular}

a. Dependent Variable: Y

b. Predictors: (Constant), X2, X1

Source: Primary data processed by SPSS 22 
International Journal of Engineering Research And Advanced Technology, Vol.7 (3), March -2021

Table 8 Multiple Linear Regression Test

\begin{tabular}{|c|c|c|c|c|c|c|}
\hline \multicolumn{7}{|c|}{ Coefficientsa } \\
\hline \multirow{2}{*}{\multicolumn{2}{|c|}{ Model }} & \multicolumn{2}{|c|}{ Unstandardized Coefficients } & \multirow{2}{*}{\begin{tabular}{|l} 
Standardized Coefficients \\
Beta
\end{tabular}} & \multirow[t]{2}{*}{$\mathrm{t}$} & \multirow[t]{2}{*}{ Sig. } \\
\hline & & B & Std. Error & & & \\
\hline \multirow{3}{*}{1} & (Constant) & 1,262 & 1,345 & & ,938 & 354 \\
\hline & X1 (working method) &,- 108 &, 050 &,- 232 & $-2,171$ & 036 \\
\hline & X2 (pert and m pert methods) &, 414 &, 040 & 1,103 & 10,319 &, 000 \\
\hline
\end{tabular}

a. Dependent Variable: Y

Source: Primary data processed by SPSS 22

\section{DISCUSSION}

\subsection{Simultaneous $\mathbf{F}$ test}

The significance test with the F test was obtained by comparing the calculated significance level (table 4.6) of Anova output with the specified significance level. Based on the analysis results in Table 4.6. obtained sig value. of $0.000<0.05$ which is determined as the level of significance, so it means that the hypothesis is accepted, or it can be interpreted that the variables X1 (Work Method) and X2 (Method Pert and M Pert) simultaneously affect the time variable (Y).

\subsection{Partial T Test}

Partial $\mathrm{T}$ test is a research hypothesis test in multiple linear regression analysis. T test aims to determine whether the independent variables X1 and X2 partially (individually) affect the dependent variable or the time dependent variable (Y). Based on the analysis results in Table 4.6 Coefficients. obtained sig value. of $0.000<0.05$ which is determined as the level of significance, so it means that the hypothesis is accepted, or it can be interpreted that the variables X1 (Work Method) and X2 (Method Pert and M Pert) simultaneously affect the time variable (Y).

\subsection{R Square Test}

Based on the SPSS output table (table 4.5), it is known that the coefficient of determination or R Square is 0.856 or the coefficient of determination R2 is 0.925. This figure implies that the variables X1 (Work Method), X2 (Method Pert and M Pert) together have an effect on Y (Time) variability of $85.6 \%$, while the variability of $14.4 \%$ is explained by variables other than X1 and X2 or other factors not studied.

\section{CONCLUSION}

Based on the results of research on the factors that influence railroad construction work with the Pert and M-PERT methods that have been carried out and analyzed, it can be concluded as follows:

The results of the questionnaire were processed using SPSs, namely the work implementation method (X1) greatly influenced time performance (Y) with 11 sub-factors consisting of 1) Line selection and geometric planning, 2) Work environment, 3) Layout arrangement to facilitate delivery / service, 4) material availability, 5) excavator selection, 6) excavator size, 7) cut \& fill monitor, 8) skilled operators, 9) work methods for distribution, 10) experience in work kind, 11).

The required human resources. And the manual method pert (X2) with 14 factors consists of 1). Distribution of activity duration, 2). Effect of activity duration, 3). Work must be faster, 4). Possibility of sharing activity duration, 5). Scheduling arrangement, 6 ). the final goal of project scheduling, 7). scheduling in activities can be completed on time, 8). break down or start the project into activities, 9). determine the estimated network time, 10). network diagram is depicted, 11). can combine activities projects, 12). calculations can be developed manually, 13) higher similarity in scheduled networks, 14). the resulting tools are accurate but not complicated. These factors, namely the Implementation Method (X1) and the Manual Method Pert (X2) affect the dependent variable (Y) time. 


\section{REFERENCES}

1. Husen, Abrar (2011), Project Management Planning, Project Scheduling, and Control. Yogyakarta.

2. Husin, Albert Eddy et al. 2015. "Forecasting Demand on Mega Infrastructure Projects: Increasing Financial Feasibility." International Journal of Technology 6(1): 73-83.

3. Harrison, FL. (1983), Advanced Project Management, Gower Publishing Company Limited Gower House, England.

4. Hamzah, S. (2004), Integration of Critical Path Method (CPM) in Road Project Planning, Transportation Journal, Vol. 4, No. 2, pp. 141-148

5. Ballesteros-Pérez, Pablo. 2017. "M-PERT: Manual Project-Duration Estimation Technique for Teaching Scheduling Basics." Journal of Construction Engineering and Management 143(9): 04017063. http://ascelibrary.org/doi/10.1061/\%28ASCE\%29CO.1943-7862.0001358.

6. Christina, Wieke Yuni, Ludfi Djakfar, and Armanur Thoyib. 2012. "The Influence of Occupational Safety and Health (K3) Culture on Construction Project Performance. " Journal of Civil Engineering, 6(1): 83-95.

7. Husin, Albert Eddy, and Reza Ferial Ashadi. 2019. "M-PERT Scheduling Method as an Alternative Solution for Estimation Accuracy Journal of Civil Engineering Application M-PERT Scheduling Method as an Alternative Solution for Project Time Estimation Accuracy ( Review ).

8. Husin, Albert Eddy, Anwar Ali, and Mawardi Amin. 2019.“Key Success Factors for Safety Programs Implementation in Indonesian Construction Projects.” International Journal of Civil Engineering and Technology (IJCIET) 10(02):1385-94.

9. Mayangkara (2016), Evaluation Of Waste Management Policy In Tpa Gunung Panggung, Tuban District, Hal $427-444$ e-ISSN: $2460-1586$.

10. Lu, By Ming, and S M Abourizk. 2000. "S IMPLIFIED CPM / PERT S IMULATION MODEL.” 126 (June): $219-26$. 